\title{
Influence of dietary supplementation of ginger powder at different levels on growth performance, haematological profiles, slaughter traits and gut morphometry of broiler chickens
}

\author{
R.S. Shewita ${ }^{1}$ \& A.E. Taha ${ }^{2 \#}$ \\ ${ }^{1}$ Department of Nutrition and Clinical Nutrition, Faculty of Veterinary Medicine, Alexandria University, Egypt \\ ${ }^{2}$ Department of Animal Husbandry and Animal Wealth Development, Faculty of Veterinary Medicine, Alexandria \\ University, Egypt
}

(Received 15 March 2018; Accepted 1 August 2018; First published online 29 November 2018)

Copyright resides with the authors in terms of the Creative Commons Attribution 4.0 South African Licence.
See: http://creativecommons.org/licenses/by/4.0/za
Condition of use: The user may copy, distribute, transmit and adapt the work, but must recognise the authors and the South African
Journal of Animal Science.

\begin{abstract}
The present investigation was performed to determine the impact of the dietary inclusion of ginger powder (Zingiber officinale) on the growth performance, immune response, slaughter traits, blood biochemistry and gut morphology of broiler chickens. One hundred and eighty unsexed broiler chicks (Avian 48) were randomly allocated to four equal groups (45 birds each) (G1, G2, G3 and G4), and each treatment had three replicates (15 birds/replicate). The G1 group was fed with basal diet, G2, G3 and G4 were received the basal diet plus $2 \mathrm{~g} / \mathrm{kg}, 4 \mathrm{~g} / \mathrm{kg}$ and $6 \mathrm{~g} / \mathrm{kg}$ ginger powder, respectively. The trial lasted for six weeks. The results demonstrated a significant decrease in the final bodyweight of G4 compared with those of G2 and G3. However, total feed intake improved in G2 and G3 and decreased in G4. The lowest feed conversion ratio (FCR) was observed in chicks of $\mathrm{G} 3$, followed by that of $\mathrm{G} 2$. At 42 days old, the gingersupplemented groups showed significant increases in hemagglutination inhibition $(\mathrm{HI})$ titre against Newcastle Disease virus. Significant increases in the leucocyte count (WBCs) and serum total protein were noticed only in G4, and cholesterol and high-density lipoprotein (HDL) levels decreased significantly in G4. In addition, the serum very-low-density lipoprotein (VLDL) and triglyceride levels decreased significantly in the gingersupplemented groups compared with $\mathrm{G} 1$, and the abdominal fat percentage significantly decreased in the G3 and G4 groups. Additionally, the ginger-supplemented groups showed higher villus lengths and greater crypt depths than the control group. Supplementation with ginger powder at a moderate level up to $4 \mathrm{~g} / \mathrm{kg}$ diet has beneficial effects on growth performance, and up to level $6 \mathrm{~g} / \mathrm{kg}$ diet improves histological gut parameters and hypolipidemic properties of broilers.
\end{abstract}

Keywords: Zingiber officinale, chicken, growth, immunity, serum parameters, carcass

\#Corresponding author: ayman_soma2007@yahoo.com, Ayman.Taha@alexu.edu.eg

\section{Introduction}

The growth and laying performances of birds are frequently improved by using growth promoters or feed additives that have a positive impact on the growth and immune responses. Among these substances, antibiotics are no longer used as feed additives, because they are associated with residues in eggs and meat products, and their use has been restricted in many countries (Botsoglou et al., 2002). The beneficial effects of natural products are greater than those observed with antibiotics (Manesh et al., 2012), including a lower cost of production and reduced toxicity hazards (Devegowda, 1996). Herbal feed additives have shown beneficial effects on broiler growth and carcass parameters (Schleicher et al., 1998). Many types and forms of herbal feed supplements have been used to maintain and improve the health of human beings (Freeman \& Kodera, 1995) and chickens (Ahmed et al., 2015). Herbal extracts can also reduce the blood cholesterol level and improve immune system functions (Mathivanan \& Kalaiarasi, 2007). Herbal supplements have antioxidant actions in broilers (Hui, 1996), activate immune responses, promote antimicrobial and anthelminthic actions and stimulate endogenous enzymes that enhance the digestion process (Omar et al., 2016). Ginger (Zingiber officinale) is widely used in many countries as a spice, food condiment and medicinal herb for certain ailments in traditional medicine (Tapsell et al., 2006; Zhang et al., 2009). The main important 
compounds in ginger are gingerol, gingerdiol and gingerdione, which can stimulate digestive enzymes, gastric secretion and blood circulation and act as an enterokinetic (Incharoen \& Yamauchi, 2009). Several pharmacological effects of ginger have been reported, such as its anti-ulcer effect and potent antibacterial, antifungal and anthelmintic activities (Akoachere et al., 2002; Demir et al., 2003; Great, 2003). Moreover, Bhandari et al. (2005) concluded that the ethanolic extract of ginger significantly reduced serum total cholesterol and triglyceride levels, increased the high-density lipoprotein (HDL) cholesterol levels, protected tissues from lipid peroxidation and exhibited a significant lipid-lowering activity in diabetic rats, while Arkan et al. (2012) suggested that ginger had a positive effect on growth performance parameters in broiler chicks. Habibi et al. (2014) and Zena et al. (2017) concluded that ginger powder in broilers did not improve growth performance. Thus, the present work aimed to study the influence of ginger powder supplementation at various levels of dietary inclusion on the growth performance, immune response, carcass characteristics, blood biochemical parameters and gut morphology of broiler chicks.

\section{Materials and Methods}

One hundred and eighty one-day-old broiler chicks (Avian 48) of mixed sexes were used in this experiment. The average weight of chicks was $45.62 \mathrm{~g}$. The chicks were wing banded and randomly allotted to four equal groups (45 chicks per group) (G1, G2, G3, and G4). Each treatment had three replicates (15 birds/replicate) and received various treatments during the experimental period (6 weeks). The chicks were housed in a room that had previously been disinfected with formaldehyde gas and were reared at $33^{\circ} \mathrm{C}$ for the first week of life, $3{ }^{\circ} \mathrm{C}$ per week after that, and $21^{\circ} \mathrm{C}$ during the fifth week of life. The chicks were supplied with continuous light for the first two days of life, and then received 23 hours of light and 1 hour of darkness per day.

The chicks were vaccinated against certain viral diseases during the trial period using live vaccine (Hitchner +IB at day 7, intermediate infectious bursal disease at days 12 and 20, Lasota at days 17 and 28) through eye drops, while inactivated Newcastle Disease and Avian Influenza Al vaccines were applied at the tenth day by intramuscular injection.

Four diets were formulated for the starter, grower and finisher phases. Ginger was purchased from a local market, sundried, ground to a fine powder, and stored in an airtight polyethene bag until required for use. The G1 group was fed with basal diet and G2, G3, and G4 groups received teh basal diet plus $2 \mathrm{~g} / \mathrm{kg}, 4$ $\mathrm{g} / \mathrm{kg}$ and $6 \mathrm{~g} / \mathrm{kg}$ ginger powder, respectively. Forty five chicks were housed for each of the four dietary treatments, with three partitions per treatment and 15 birds in each partition. The experimental procedures were performed according to the guidelines of the National Institutes of Health $(\mathrm{NIH})$ for the Care and Use of Laboratory Animals and certified by the Committee of the Faculty of Veterinary Medicine, Alexandria University, Egypt. The diets were formulated according to the NRC (1994), and the ingredient composition and analysis (AOAC, 1985) of the basal diet (BD) are presented in Tables 1 and 2.

The chicks were weighed individually to the nearest gram at the beginning of the experiment and every week for six weeks. The difference between two successive weights was calculated as the bodyweight gain. The daily feed intake was calculated as the difference between the offered feed and the remaining feed at 8 am daily. The feed conversion ratio (FCR) was calculated by dividing the total feed intake by the total body gain. Mortality percentages were calculated as a percentage of dead chicks from the total number of each group.

Three blood samples were collected from each replicate at the end of the experimental period and then left to coagulate at room temperature. The separation of serum was conducted by centrifugation at $3000 \mathrm{rpm}$ for 10 minutes. Serum total protein, albumin (globulin was calculated) concentrations, the activities of the enzymes, alanine aminotransferase (ALT, EC 2.6.1.2) and aspartate aminotransferase (AST, EC 2.6.1.1) were measured as well, total cholesterol (low-density lipoprotein (LDL) and HDL ). The very-lowdensity lipoprotein (VLDL, calculated), triglycerides and glucose levels were determined according to Doumas et al. (1981), Reinhold (1953), Reitman \& Frankel (1957), Kind \& King (1954), Sidney \& Barnard (1973), Giorgio et al. (1974) and Trinder (1969), respectively. Moreover, three additional blood samples were collected from each replicate in tubes containing anticoagulant to determine blood haemoglobin ( $\mathrm{Hb})$ and packed cell volume (PCV), according to Eilers (1967). Red blood cells and leucocyte count (WBC) were counted according to Hepler (1966) and Lucas \& Jamroz (1961), respectively.

Hemagglutination inhibition $(\mathrm{HI})$ : Six blood samples were collected from each group at 21, 28, 35 and 42 days old. The blood samples were centrifuged to separate the serum and estimate the antibody titre against the ND using a hemagglutination inhibition test, according to Grimes (2002). 
Table 1 Percentage of ingredients in the basal diets

\begin{tabular}{lccc}
\hline Ingredients, \% & Starter & Grower & Finisher \\
\hline Yellow corn & 55 & 61.79 & 68.2 \\
Soybean meal & 32.4 & 26 & 21.2 \\
Corn gluten meal & 5.5 & 5.4 & 4 \\
Limestone & 1.1 & 1.12 & 1.1 \\
Dicalcium phosphate & 1.75 & 1.5 & 1.3 \\
Vit Premix & 0.15 & 0.15 & 0.15 \\
Min Premix & 0.15 & 0.15 & 0.15 \\
NaCl & 0.3 & 0.3 & 0.3 \\
DL-Methionine & 0.31 & 0.3 & 0.2 \\
L-Lysine (HCL) & 0.34 & 0.29 & 0.35 \\
Vegetable oils & 3 & 3 & 3.05 \\
\end{tabular}

\footnotetext{
${ }^{1}$ Every $1.5 \mathrm{~kg}$ contains thiamine $2000 \mathrm{mg}$, riboflavin $6000 \mathrm{mg}$, pyridoxine $5000 \mathrm{mg}$, cyanocobalamin $20 \mathrm{mg}$, niacin $45000 \mathrm{mg}$, biotin $75 \mathrm{mg}$, folic acid $2000 \mathrm{mg}$ and pantothenic acid $12000 \mathrm{mg}$, retinol $7200 \mathrm{mg}$, cholecalciferol $75 \mathrm{mg}$, tocopherol $40000 \mathrm{mg}$ and menadione $3000 \mathrm{mg}$

${ }^{2}$ Every $1.5 \mathrm{~kg}$ contains manganese100 $000 \mathrm{mg}$, zinc $600000 \mathrm{mg}$, iron $30000 \mathrm{mg}$, copper $10000 \mathrm{mg}$, iodine $1000 \mathrm{mg}$, selenium $200 \mathrm{mg}$ and cobalt $100 \mathrm{mg}$
}

Table 2 Analysed ${ }^{2}$ and calculated ${ }^{3}$ values of the basal diets $(\mathrm{g} / \mathrm{kg})$ used in the experiment

\begin{tabular}{lccc}
\hline Items & Starter & Grower & Finisher \\
\hline Dry matter $^{2}$ & 868 & 874 & 869 \\
ME MJ/kg & & 13.03 & 13.28 \\
Crude & 12.69 & 193.4 & 178.0 \\
protein $^{2}$ & 221 & 6.0 & 5.1 \\
Methionine $^{3}$ & 6.9 & 61.3 & 71.9 \\
Crude fat $^{3}$ & 52.1 & 43.3 & 47.5 \\
Crude fibre $^{2}$ & 47.0 & 55.3 & 5.74 \\
Ash $^{2}$ & 52.5 & & \\
\hline
\end{tabular}

ME: metabolizable energy

Phagocytic activity (PA) and phagocytic index (PI): These parameters were estimated as described by Kawahara et al. (1991). Briefly, blood samples of one $\mathrm{mL}$ each were collected at the end of the experiment from three slaughtered birds per group. The samples were citrated and 50 micrograms of Candida albicans culture was added to each sample. The samples were put in a shaker water bath at $24{ }^{\circ} \mathrm{C}$ for four hours. Smears of the samples were stained with Giemsa stain. The proportion of macrophages that contained intracellular yeast cells was determined in a random sample of 300 macrophages and expressed as the percentage of PA. The PI was calculated according to the following equation:

\section{$\mathrm{PI}=$ number of phagocytized cells $\mathrm{X} 100 /$ number of phagocytic cells}

Differential leucocytic count: At the end of the study period, blood films were prepared as described (Lucky, 1977). Ten drops of May-Grunwald stain were added to an equal amount of distilled water on a dry unfixed smear, mixed, and left for one minute for staining. After decanting the dye (without rinsing), a diluted Giemsa stain was poured over the film as a counterstain, left for 20 minutes, then rinsed under a water current and examined by an oil emersion lens. Absolute and percentage values were calculated for each cell type (Maxine, 1985). 
At the end of the experiment, three birds were selected at random from each replicate. The birds were fasted for eight hours before weighing, and then slaughtered for complete bleeding. Weights of the hot carcass, heart, liver, gizzard, proventriculus, abdominal fat and lymphoid organs (bursa, thymus and spleen) were calculated as a percentage of slaughter weight.

Immediately after slaughtering, the small intestine was dissected free of its mesentery. Small specimens were collected from the control and treated chicks. Specimens were immediately fixed in neutral buffered formalin (10\%) for 24 hours. Fixed specimens were processed through the paraffin-embedding technique. Sections at four micrometres thick were prepared and stained by haematoxylin and eosin (HE), according to Bancroft et al. (1996), for the histopathological examination.

A quantitative computerized morphometric analysis was performed on images of the prepared sections. The images were analysed using ImageJ software (Bethesda, MD, USA) to measure the villi height, crypt depth and villi width at the crypt/villus junction as well as the tip. The measurement was based on the reported mean value of 15 villi/sample (x10).

Data were subjected to an analysis of variance (ANOVA) using SAS (2004), followed by Duncan's test to estimate the significance between treated groups. Means were significant at $P<0.05$. The geometric mean of the estimated Hemagglutination inhibition titres was calculated according to Brugh (1978).

\section{Results}

The effect of dietary supplementation of ginger powder at levels of $0 \mathrm{~g} / \mathrm{kg}, 2 \mathrm{~g} / \mathrm{kg}, 4 \mathrm{~g} / \mathrm{kg}$ and $6 \mathrm{~g} / \mathrm{kg}$ diet on the performance traits of broiler chicks during the study period is presented in Table 3 . The ANOVA showed non-significant differences in the initial BW of broiler chicks between groups. In addition, during the sixth week of life, broilers of the G2 (ginger at $2 \mathrm{~g} / \mathrm{kg}$ diet) and G3 (ginger at $4 \mathrm{~g} / \mathrm{kg}$ diet) groups recorded higher non-significant $(P>0.05)$ increases in BW than the birds of the $\mathrm{G} 1$, although the birds of $\mathrm{G} 2$ and $\mathrm{G} 3$ had higher $(P<0.05)$ final BW compared with those of $\mathrm{G} 4$ (ginger at $6 \mathrm{~g} / \mathrm{kg}$ diet).

Concerning total bodyweight gain (BWG), total feed intake (FI), FCR and mortality percentages, the results showed that the total BWG of G4 was significantly lower than those of G2 and G3. Differences in total BWG among the G1, G2 and G3 groups were not significant. Concerning the total FI, a non-significant increase was observed for G2 and G3 compared with G1. Increasing the ginger powder level in the diet to the level of $6 \mathrm{~g} / \mathrm{kg}$ diet (G4) resulted in a non-significant $(P>0.05)$ decrease of total FI compared with that of the G1. G3 had the best FCR, followed by G2. Group G4, which was fed the highest level of ginger powder (6 $\mathrm{g} / \mathrm{kg}$ diet), showed an increase in the FCR. Mortalities were not recorded in G3 and G4.

Table 3 Effect of dietary ginger powder supplementation on the average growth performance of broiler chickens (means \pm SE (standard error))

\begin{tabular}{lcccc}
\hline Parameter & G1 & G2 & G3 & G4 \\
\hline Initial BW & $45.64 \pm 0.48$ & $45.60 \pm 0.43$ & $45.63 \pm 0.55$ & $45.62 \pm 0.46$ \\
Final BW & $2524^{\mathrm{ab}} \pm 82.15$ & $2650^{\mathrm{a}} \pm 54.67$ & $2681^{\mathrm{a}} \pm 52.39$ & $2435^{\mathrm{b}} \pm 73.01$ \\
Total BWG & $2479^{\mathrm{ab}} \pm 81.69$ & $2604^{\mathrm{a}} \pm 54.25$ & $2635^{\mathrm{a}} \pm 51.88$ & $2390^{\mathrm{b}} \pm 72.57$ \\
Total BWG (RTC) & 100 & 105.06 & 106.31 & 96.41 \\
Total FI & $4592^{\mathrm{ab}} \pm 69.64$ & $4760^{\mathrm{a}} \pm 68.35$ & $4657^{\mathrm{ab}} \pm 46.24$ & $4533^{\mathrm{b}} \pm 61.93$ \\
Total Fl (RTC) & 100 & 103.66 & 101.43 & 98.71 \\
FCR & $1.85^{\mathrm{a}} \pm 0.04$ & $1.83^{\mathrm{ab}} \pm 0.04$ & $1.77^{\mathrm{b}} \pm 0.02$ & $1.90^{\mathrm{a}} \pm 0.04$ \\
FCR (RTC) & 100 & 98.79 & 95.53 & 102.52 \\
Mortality \% & 4.4 & 2.2 & 0 & 0 \\
\hline
\end{tabular}

RTC: relative to control

a,b Means with different superscripts in the same row differ significantly at $P<0.05$

G1: control group, G2: $2 \mathrm{~g}$ ginger powder/kg diet, G3: $4 \mathrm{~g}$ ginger powder/kg diet, G4: $6 \mathrm{~g}$ ginger powder/kg diet BW: body weight, BWG: body weight gain, FI: feed intake, FCR: Feed conversion ratio

The effects of dietary ginger powder supplementation on certain blood parameters of the broiler chickens are listed in Table 4. WBC count showed non-significant increases in G2 and G3, but significant 
increases $(P<0.05)$ in $\mathrm{G} 4$ compared with $\mathrm{G}$, while non-significant differences were recorded among the groups for red blood cell count (RBC), Hb concentration and PCV\%.

Table 4 Effect of dietary ginger powder supplementation on the blood parameters (White blood corpuscles (WBCs), red blood corpuscles (RBCs), haemoglobin ( $\mathrm{Hb})$, packed cell volume (PCV)) of the broiler chickens (means $\pm \mathrm{SE}$ )

\begin{tabular}{lcccc}
\hline Parameters & G1 & G2 & G3 & G4 \\
\hline WBCs $\left(10^{3}\right)$ & $16.87^{\mathrm{b}} \pm 0.65$ & $18.28^{\mathrm{ab}} \pm 0.59$ & $17.50^{\mathrm{ab}} \pm 0.50$ & $18.76^{\mathrm{a}} \pm 0.18$ \\
$\mathrm{RBCs}\left(10^{6}\right)$ & $2.79 \pm 0.03$ & $2.83 \pm 0.07$ & $2.76 \pm 0.05$ & $2.79 \pm 0.11$ \\
$\mathrm{Hb} \%$ & $10.33 \pm 0.42$ & $10.64 \pm 1.07$ & $9.61 \pm 0.68$ & $10.40 \pm 1.18$ \\
PCV\% & $32.08 \pm 2.02$ & $34.21 \pm 3.59$ & $30.60 \pm 2.74$ & $32.99 \pm 4.34$ \\
\hline
\end{tabular}

a,b Means with different superscripts in the same row differ significantly at $P<0.05$

G1: control group, G2: $2 \mathrm{~g}$ ginger powder $/ \mathrm{kg}$ diet, G3: $4 \mathrm{~g}$ ginger powder $/ \mathrm{kg}$ diet, G4: $6 \mathrm{~g}$ ginger powder $/ \mathrm{kg}$ diet WBC: White blood corpuscles, RBC: red blood corpuscles, Hb: haemoglobin, PCV: packed cell volume

Table 5 Effect of dietary ginger powder supplementation on certain blood serum parameters of broiler chickens (means $\pm \mathrm{SE}$ )

\begin{tabular}{lcccc}
\hline Parameters & G1 & G2 & G3 & G4 \\
\hline Total protein (g/dL) & $6.12^{\mathrm{b}} \pm 0.02$ & $6.08^{\mathrm{b}} \pm 0.03$ & $6.16^{\mathrm{b}} \pm 0.04$ & $6.31^{\mathrm{a}} \pm 0.03$ \\
Albumin (g/dL) & $4.94 \pm 0.22$ & $5.17 \pm 0.06$ & $5.29 \pm 0.02$ & $5.32 \pm 0.01$ \\
Globulin (g/dL) & $1.19 \pm 0.20$ & $0.91 \pm 0.04$ & $0.88 \pm 0.01$ & $0.99 \pm 0.02$ \\
A/G ratio & $4.44^{\mathrm{b}} \pm 0.82$ & $5.68^{\mathrm{ab}} \pm 0.30$ & $6.03^{\mathrm{a}} \pm 0.07$ & $5.36^{\mathrm{ab}} \pm 0.12$ \\
Cholesterol (mg/dL) & $205.23^{\mathrm{a}} \pm 0.84$ & $201.57^{\mathrm{ab}} \pm 1.17$ & $197.97^{\mathrm{ab}} \pm 3.93$ & $194.70^{\mathrm{b}} \pm 3.14$ \\
HDL (mg/dL) & $54.50^{\mathrm{a}} \pm 0.99$ & $52.97^{\mathrm{a}} \pm 0.64$ & $53.43^{\mathrm{a}} \pm 0.66$ & $49.87^{\mathrm{b}} \pm 0.79$ \\
LDL (mg/dL) & $109.69 \pm 1.71$ & $109.46 \pm 1.12$ & $105.10 \pm 4.00$ & $105.59 \pm 4.09$ \\
VLDL (mg/dL) & $41.04^{\mathrm{a}} \pm 0.06$ & $39.14^{\mathrm{b}} \pm 0.45$ & $39.43^{\mathrm{b}} \pm 0.57$ & $39.25^{\mathrm{b}} \pm 0.46$ \\
Triglyceride (mg/dL) & $205.20^{\mathrm{a}} \pm 0.30$ & $195.70^{\mathrm{b}} \pm 2.25$ & $197.17^{\mathrm{b}} \pm 2.85$ & $196.23^{\mathrm{b}} \pm 2.28$ \\
Cho/HDL ratio & $3.77 \pm 0.08$ & $3.81 \pm 0.05$ & $3.71 \pm 0.08$ & $3.91 \pm 0.11$ \\
Glucose (mg/dL) & $214.83^{\mathrm{a}} \pm 1.61$ & $211.27^{\mathrm{ab}} \pm 2.49$ & $205.93^{\mathrm{bc}} \pm 1.21$ & $204.07^{\mathrm{c}} \pm 0.94$ \\
AST (U/100 mL) & $39.67 \pm 4.67$ & $30.67 \pm 2.03$ & $35.00 \pm 4.16$ & $33.67 \pm 4.41$ \\
ALT (U/100 mL) & $88.33 \pm 2.03$ & $92.67 \pm 3.18$ & $91.00 \pm 1.15$ & $85.33 \pm 2.40$ \\
& & & &
\end{tabular}

a,b,c Means with different superscripts in the same row differ significantly at $P<0.05$

G1: control group, G2: $2 \mathrm{~g}$ ginger powder/kg diet, G3: $4 \mathrm{~g}$ ginger powder/kg diet, G4: $6 \mathrm{~g}$ ginger powder $/ \mathrm{kg}$ diet

A/G: albumin/globulin ratio, HDL: high density lipoprotein, LDL: low density lipoprotein, VLDL: very low density lipoprotein, Cho/HDL: cholesterol/high density lipoprotein ratio, AST: aspartate aminotransferase, ALT: Alanine aminotransferase

Table 5 shows the effects of ginger powder supplementation on certain blood serum parameters of the broiler chicks. A significant increase in the serum total protein (TP) was observed in the G4 group compared with those in the other treatment groups and the control. On the other hand, a significant $(P<0.05)$ decrease in cholesterol levels was observed in the G4 group compared with that in the control group, although this decrease was not significant $(P>0.05)$ compared with those in the other ginger-treated groups. The HDL levels significantly decreased in the G4 group compared with those in all the experimental groups. Moreover, the VLDL and triglyceride levels significantly decreased $(P<0.05)$ in all groups supplemented with ginger compared with those in the control. In addition, ginger powder supplementation led to a significant decrease in the serum glucose level $(P<0.05)$ in $\mathrm{G} 3$ and $\mathrm{G} 4$ compared with that in G1. Significant differences in the 
serum AST and ALT activities were not observed among the experimental groups fed diets without or with ginger powder at various levels.

Table 6 shows the effect of dietary supplementation with ginger powder at levels of $2 \mathrm{~g} / \mathrm{kg}, 4 \mathrm{~g} / \mathrm{kg}$ and $6 \mathrm{~g} / \mathrm{kg}$ diet compared with that of the control diet with the Hemagglutination inhibition $(\mathrm{HI})$ titre to the Newcastle Disease Virus.

The data showed that significant differences in the $\mathrm{HI}$ titre did not occur among the experimental groups at days 21 and 28, whereas the $\mathrm{HI}$ titre started to increase with higher levels of ginger supplementation (G3 and G4) at day 35. At day 42, all groups fed diets supplemented with ginger powder showed significant $(P<0.05)$ increases in the $\mathrm{HI}$ titre compared with the control group.

Table 6 Geometric mean antibody titre (log2) against the Newcastle Disease virus of groups of broiler chickens supplemented with different levels of ginger powder (means \pm SE)

\begin{tabular}{lcccc}
\hline Age (days) & G1 & G2 & G3 & G4 \\
\hline 21 & $2.67 \pm 0.33$ & $3.33 \pm 0.67$ & $3.00 \pm 0.58$ & $3.67 \pm 0.33$ \\
28 & $2.33 \pm 0.33$ & $2.67 \pm 0.67$ & $3.00 \pm 0.58$ & $3.33 \pm 0.33$ \\
35 & $2.67^{\mathrm{b}} \pm 0.33$ & $2.33^{\mathrm{b}} \pm 0.33$ & $3.00^{\mathrm{a}} \pm 0.00$ & $3.67^{\mathrm{a}} \pm 0.33$ \\
42 & $1.67^{\mathrm{b}} \pm 0.33$ & $3.33^{\mathrm{a}} \pm 0.67$ & $3.33^{\mathrm{a}} \pm 0.33$ & $3.67^{\mathrm{a}} \pm 0.33$ \\
\hline
\end{tabular}

${ }^{a, b}$ Means with different superscripts in the same row differ significantly at $P<0.05$

G1: control group, G2: $2 \mathrm{~g}$ ginger powder/kg diet, G3: $4 \mathrm{~g}$ ginger powder $/ \mathrm{kg}$ diet, G4: $6 \mathrm{~g}$ ginger powder $/ \mathrm{kg}$ diet

Differential leukocytic count and phagocytosis: The effects of dietary supplementation of ginger powder at levels of $2 \mathrm{~g} / \mathrm{kg}, 4 \mathrm{~g} / \mathrm{kg}$ and $6 \mathrm{~g} / \mathrm{kg}$ diet compared with the control diet on differential leukocytic counts and phagocytosis are summarized in Table 7. Significant differences did not occur in the differential leukocytic counts among the groups supplemented with ginger powder and the control group. The results showed a non-significant difference in the PA and PI between the ginger-supplemented groups and that in the control group. The PA was numerically (approaching significant) increased by approximately $7.2 \%, 7.2 \%$ and $9.6 \%$ in $\mathrm{G} 2, \mathrm{G} 3$, and $\mathrm{G} 4$, respectively, compared with that in the control group.

Table 7 Effect of dietary ginger powder supplementation on differential leukocytic counts (\%) and the phagocytic activity and phagocytic index of the broiler chick groups (means \pm SE)

\begin{tabular}{lcccc}
\hline Parameters & G1 & G2 & G3 & G4 \\
\hline Lymphocytes & $57.67 \pm 0.88$ & $59.00 \pm 2.65$ & $55.33 \pm 1.67$ & $56.00 \pm 3.61$ \\
Heterophils & $29.00 \pm 1.00$ & $30.00 \pm 2.08$ & $31.33 \pm 2.03$ & $30.67 \pm 3.48$ \\
Basophile & $3.67 \pm 0.67$ & $2.67 \pm 0.67$ & $3.33 \pm 0.67$ & $4.00 \pm 0.58$ \\
Eosinophil & $3.00 \pm 0.58$ & $2.67 \pm 0.67$ & $3.33 \pm 0.33$ & $3.67 \pm 0.33$ \\
Monocytes & $6.67 \pm 0.88$ & $5.67 \pm 0.33$ & $6.67 \pm 0.33$ & $5.67 \pm 0.33$ \\
PA & $27.67 \pm 0.88$ & $29.67 \pm 2.67$ & $29.67 \pm 0.67$ & $30.33 \pm 4.33$ \\
PI & $4.00 \pm 0.58$ & $5.33 \pm 0.88$ & $4.33 \pm 0.67$ & $4.67 \pm 1.76$
\end{tabular}

a,b Means with different superscripts in the same row differ significantly at $P<0.05$

G1: control group, G2: $2 \mathrm{~g}$ ginger powder/kg diet, G3: $4 \mathrm{~g}$ ginger powder $/ \mathrm{kg}$ diet, G4: $6 \mathrm{~g}$ ginger powder $/ \mathrm{kg}$ diet

PA: phagocytic activity, PI: phagocytic index

Non-significant differences were observed in the slaughter traits, including the dressing percentage, relative liver, heart, spleen, proventriculus and gizzard weight (\%), among the groups receiving different levels of ginger powder (Table 8). However, the relative abdominal fat weight was significantly $(P<0.05)$ decreased in G3 and G4 compared with those in the other groups. The relative weights of the thymus gland and bursa increased in all groups supplemented with ginger compared with those in the control. 
The mucosa and submucosa of the jejunum from the control and ginger-treated broiler chickens showed normal histological structures of their villi and associated crypt, tunica muscularis and submucosal tissues (Figure 1).

Table 8 Effect of dietary ginger powder supplementation on some slaughter traits of broiler chickens (means $\pm \mathrm{SE})$

\begin{tabular}{lcccc}
\hline Items & G1 & G2 & G3 & G4 \\
\hline Slaughter weight (g) & $2511^{\mathrm{b}} \pm 32.4$ & $2623^{\mathrm{a}} \pm 14.5$ & $2663^{\mathrm{a}} \pm 38.5$ & $2481^{\mathrm{b}} \pm 34.9$ \\
Hot carcass weight (g) & $1879.2 \pm 45.9$ & $1987.5 \pm 48.4$ & $1987.7 \pm 62.7$ & $1859.1 \pm 13.5$ \\
Hot dressing (\%) & $74.81 \pm 0.95$ & $75.76 \pm 1.63$ & $74.59 \pm 1.32$ & $74.95 \pm 1.49$ \\
Liver weight (\%) & $2.05 \pm 0.38$ & $1.90 \pm 0.08$ & $1.91 \pm 0.17$ & $1.86 \pm 0.16$ \\
Heart weight (\%) & $0.43 \pm 0.05$ & $0.39 \pm 0.01$ & $0.42 \pm 0.02$ & $0.37 \pm 0.02$ \\
Spleen weight (\%) & $0.09 \pm 0.01$ & $0.10 \pm 0.01$ & $0.10 \pm 0.01$ & $0.07 \pm 0.01$ \\
Proventriculus weight (\%) & $0.28 \pm 0.02$ & $0.25 \pm 0.01$ & $0.30 \pm 0.05$ & $0.37 \pm 0.07$ \\
Gizzard weight (\%) & $1.07 \pm 0.05$ & $1.01 \pm 0.08$ & $1.19 \pm 0.17$ & $1.14 \pm 0.04$ \\
Abdominal fat weight (\%) & $2.42^{\mathrm{a}} \pm 0.27$ & $2.06^{\mathrm{ab}} \pm 0.16$ & $1.41^{\mathrm{c}} \pm 0.05$ & $1.54^{\mathrm{bc}} \pm 0.07$ \\
Thymus gland weight (\%) & $0.23 \pm 0.04$ & $0.27 \pm 0.05$ & $0.26 \pm 0.06$ & $0.27 \pm 0.03$ \\
Bursa weight (\%) & $0.04 \pm 0.01$ & $0.07 \pm 0.03$ & $0.08 \pm 0.03$ & $0.06 \pm 0.03$ \\
\hline
\end{tabular}

${ }^{a, b, c}$ Means with different superscripts in the same row differ significantly at $P<0.05$

G1: control group, G2: $2 \mathrm{~g}$ ginger powder/kg diet, G3: $4 \mathrm{~g}$ ginger powder/kg diet, G4: $6 \mathrm{~g}$ ginger powder/kg diet $\%$ : relative to slaughter weight

As presented in Table 9, significant increases in villus height and villus width at the crypt/villus junction $(P<0.05)$ were reported for all ginger-treated groups relative to G1. However, the villus width at the tip and villus height/crypt depth decreased $(P>0.05)$ compared with those in the control group (G1). The G3 group recorded the highest crypt depth $(P<0.05)$. In addition, the crypt depths of groups $\mathrm{G} 2$ and $\mathrm{G} 4$ were significantly higher $(p<0.05)$ than those in $\mathrm{G} 1$.

Table 9 Measurement of the intestinal villus height and width and crypt depth in experimental groups (means $\pm \mathrm{SE})$

\begin{tabular}{lcccc}
\hline Parameter $(\boldsymbol{\mu m})$ & G1 & G2 & G3 & G4 \\
\hline Villus height & $584.2^{\mathrm{b}} \pm 39.74$ & $750.3^{\mathrm{a}} \pm 8.71$ & $787.8^{\mathrm{a}} \pm 13.10$ & $728.0^{\mathrm{a}} \pm 14.56$ \\
Width of the villus at the tip & $77.81^{\mathrm{a}} \pm 18.46$ & $36.96^{\mathrm{b}} \pm 4.94$ & $54.26^{\mathrm{ab}} \pm 9.30$ & $34.74^{\mathrm{b}} \pm 4.82$ \\
Width of the villus at the crypt/villus junction & $55.95^{\mathrm{b}} \pm 7.06$ & $80.77^{\mathrm{a}} \pm 2.74$ & $83.61^{\mathrm{a}} \pm 8.68$ & $71.40^{\mathrm{ab}} \pm 3.78$ \\
Crypt depth & $56.39^{\mathrm{c}} \pm 5.51$ & $102.21^{\mathrm{b}} \pm 8.18$ & $139.09^{\mathrm{a}} \pm 18.69$ & $80.38^{\mathrm{bc}} \pm 10.49$ \\
Villus height / crypt depth & $10.93^{\mathrm{a}} \pm 1.02$ & $7.69^{\mathrm{bc}} \pm 0.56$ & $6.40^{\mathrm{c}} \pm 0.73$ & $10.23^{\mathrm{ab}} \pm 1.29$
\end{tabular}

a,b,c Means with different superscripts in the same row differ significantly at $P<0.05$

G1: control group, G2: 2 g ginger powder/kg diet, G3: $4 \mathrm{~g}$ ginger powder/kg diet, G4: $6 \mathrm{~g}$ ginger powder/kg diet 

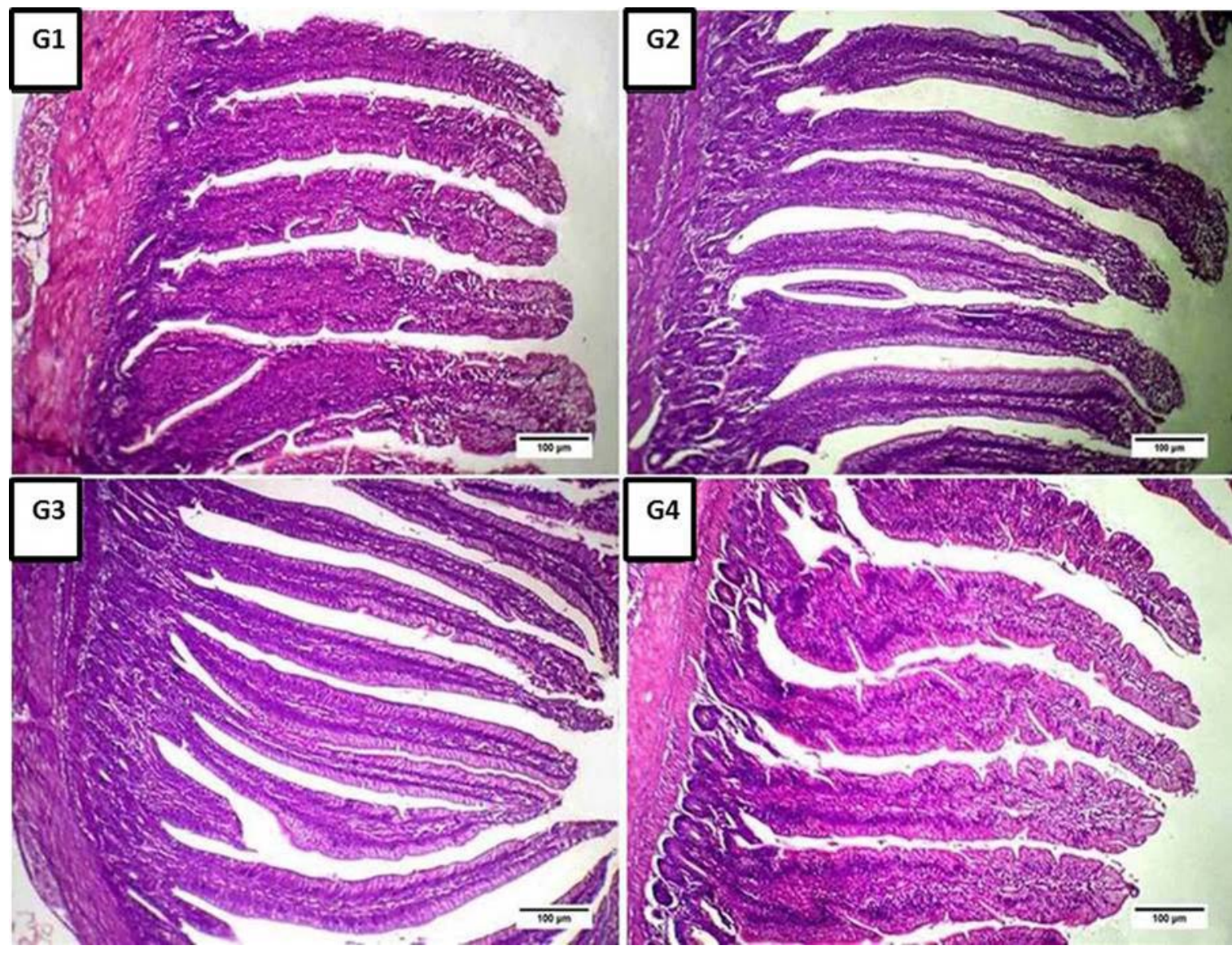

Figure 1 Representative photomicrograph of the jejunum mucosa and submucosa of control and ginger- treated broiler chickens, stained with HE, Bar: $100 \mu \mathrm{m}$ : (G1) control untreated chicken; (G2) chicken treated with 2 g/kg diet ginger; (G3) chicken treated with $4 \mathrm{~g} / \mathrm{kg}$ diet ginger; and (G4) chicken treated with $6 \mathrm{~g} / \mathrm{kg}$ diet ginger. Light microscopic examination revealed normal histological structures of the intestinal villi and their crypts, tunica muscularis and submucosa of jejunum

\section{Discussion}

The parameters of growth performance, immune response, liver biomarkers, lipid profiles, slaughter traits and gut morphometry were examined in the current study. These parameters are good indicators of the potential improvement effect of ginger supplementation at different levels on broiler performance. In the present study, final body weight, total body gain, total feed intake and feed conversion ratio improved after supplementation of ginger at levels of $2 \mathrm{~g} / \mathrm{kg}$ diet and $4 \mathrm{~g} / \mathrm{kg}$ diet. Meanwhile the broilers that received higher level of ginger (6 $\mathrm{g} / \mathrm{kg}$ diet) showed decreased BW, total BWG, total FI and increment in FCR. These findings were in accord with those reported by Herawati \& Marjuki (2011), who found that increasing ginger to a ratio up to $2 \%(20 \mathrm{~g} / \mathrm{kg}$ diet) reduced the feed intake and total weight gain. In addition, the results are consistent with the report of Herawati (2010), who stated that broilers fed $2 \%$ dried supplementary red ginger meal had significantly lower feed intake than those on the control diet, and the decreased feed intake resulted in a corresponding decrease in weight gain as the supplement levels were increased. Zhang et al. (2009) reported no significant effects of dietary ginger supplementation $(5 \mathrm{~g} / \mathrm{kg})$ on the weight gain of broilers. On the other hand, Onimisi et al. (2005) and Ademola et al. (2009) observed that ginger increased the BW when included in the diet up to $2 \%$ level. The reduced BW observed for the diet with $6 \mathrm{~g}$ ginger $/ \mathrm{kg}$ diet could be related to the reduction in feed intake and subsequent reduction in BW with the excessive use of herbal plants because of the strong bitter taste (Ficker et al., 2003; Hosseini, 2011). The findings of FCR are consistent with Arkan et al. (2012), who concluded that birds fed $0.1 \%$ and $0.2 \%$ ginger had better FCRs. The improvement of the final BW, total FI, total BWG and FCR in G2 and G3 may be attributed to the potential of ginger and its active ingredients to stimulate the salivary and gastric glands secretions decrease the levels of pathogenic bacteria and form more stable intestinal flora with subsequent improved digestibility (Great, 2003; Incharoen \& Yamauchi, 2009). 
Regarding total protein, ginger in the highest level $(6 \mathrm{~g} / \mathrm{kg}$ diet) had greater TP than other groups. These results are consistent with those of Zhang et al. (2009), who concluded that the inclusion of ginger in the diet at $5 \mathrm{~g} / \mathrm{kg}$ diet increased TP and lowered cholesterol concentrations in the serum of broilers. The same authors suggested that the increased TP concentration in the serum of broilers supplemented with ginger is consistent with the enhanced antioxidant enzyme activity.

The lipid profile parameters including total cholesterol, total triglyceride, HDL, LDL and VLDL were decreased in ginger-supplemented groups, suggesting the hypolipidemic effect of ginger. This finding is consistent with those of Ademola et al. (2009), who found that the dietary supplementation of ginger significantly decreased the serum cholesterol and triglyceride levels in broilers. Moreover, the total cholesterol and serum LDL concentrations significantly decreased in the ginger-supplemented group (Shanoon et al., 2012). Using dietary ginger can reduce the total serum cholesterol by inhibiting hydroxylmethyl-glutaryl-coenzyme-A reductase (HMG-CoA) or by increasing the excretion of bile acid and faecal cholesterol (Malekizadeh et al., 2012). In addition, ginger powder supplementation led to a significant decrease in the serum glucose level $(P<0.05)$ in $\mathrm{G} 3$ and $\mathrm{G} 4$ compared with that in $\mathrm{G} 1$. This result agrees with Saeid et al. (2010), who found that the serum glucose level decreased in broilers supplemented with $0.4 \%$ and $0.6 \%$ aqueous ginger extract. The accepted explanation for this significantly reduction may be inhibition of hepatic phosphorylase enzyme by dietary supplementation of ginger, where it is able to abrogate the breakdown of hepatic glycogen storages. Likewise, it can stimulate the activity of the enzymes, improving glycogen synthesis (Zhang \& Tan, 2003).

The groups supplemented with different levels of ginger had improved $\mathrm{HI}$ titre against Newcastle Disease at 42 days old in comparison with control. These findings are consistent with those of Nidaullah et al. (2010) and Azhir et al. (2012), who observed that aqueous extracts of ginger had a better performance as an immune stimulant against Newcastle Disease. However, ginger did not affect differential leukocytic count, red blood corpuscles (RBCs), haemoglobin ( $\mathrm{Hb} \%)$ and packed cell volume (PCV\%). These findings are consistent with those of George et al. (2015), who found that haematological parameters, including differential leukocytic counts, such as lymphocytes and neutrophils, and $\mathrm{Hb}$ concentration and PCV were not affected by the dietary supplementation of ginger at $2 \mathrm{~g} / \mathrm{kg}, 4 \mathrm{~g} / \mathrm{kg}$, and $6 \mathrm{~g} / \mathrm{kg}$ diet.

In the current study, phagocytic activity was increased in ginger-supplemented groups. This may be attributed to ginger-associated immune enhancement. These results are consistent with those of Al-Shuwaili et al. (2015), who recognized that ginger supplements in broiler chicken diets have a strong stimulating effect on the immune and digestive systems.

Concerning the slaughter traits, the relative weights of various organs were not affected by ginger supplementation, except for the decreased relative weight of abdominal fat. Similar to these results, El-Deek et al. (2002) demonstrated that carcass weight did not differ between the control and ginger-treated broilers. Additionally, Onu (2010) and Erener et al. (2005) did not observe a significant effect for ginger powder supplementation in various levels on the slaughter traits of broilers, while Ademola et al. (2009) stated that the dietary supplementation of ginger significantly decreased the abdominal fat of broilers. This reduction in the abdominal fat percentage in ginger-supplemented chicks may be attributed to the lipid-lowering effect of ginger (Sharma et al., 1996).

Analysis of intestinal morphometry exhibited significant increment in villus height in all gingersupplemented groups. This increment indicates an increase in intestinal surface area and absorptive strength Oladele et al. (2012), with subsequent elevation in BW and improving in FCR in these groups. Likewise, mean value of crypt depth was significantly raised in groups supplemented with ginger at levels 2 and $4 \mathrm{~g} / \mathrm{kg}$ diet. It is well known that crypt cells are responsible for the secretion of electrolytes with the subsequent release of water into the intestinal lumen, which could improve nutrient digestibility (Bowen, 2011). These findings were in agreement with those reported by Karangiya et al. (2016).

\section{Conclusion}

Based on the current findings, dietary supplementation of ginger powder at level up to $4 \mathrm{~g} / \mathrm{kg}$ diet plays a role in improving broiler growth performance and gut morphometry. Moreover, inclusion of ginger up to level $6 \mathrm{~g} / \mathrm{kg}$ diet contributed to improvements of the immune response, and a reduction of the cholesterol, triglyceride and glucose levels.

\section{Acknowledgment}

We gratefully acknowledge Egyptian Knowledge Bank (EKB) (www.ekb.eg) for supporting the English editing of the manuscript at the author services of Springer Nature.

\section{Author's contribution}

RSS planned, designed, and supervised the experiment. RSS and AET performed the complete experimental trial. AET analysed the data and helped in the extraction of plant material. 


\section{Conflict of Interest Declaration}

The authors declare that they have no competing interests.

\section{References}

Ademola, S.G., Farinu, G.O. \& Babatunde, G.M., 2009. Serum lipid, growth and hematological parameters of broilers fed garlic, ginger and their mixtures. World Journal of Agricultural Sciences 5 (1), 99-104. Doi:10.1.1.415.1931.pdf./citeseerx.ist.psu.edu.

Ahmed, H.A., Sadek, K.M. \& Taha, A.E., 2015. Impact of two herbal seeds supplementation on growth performance and some biochemical blood and tissue parameters of broiler chickens. World Academy of Science, Engineering and Technology, International Journal of Animal and Veterinary Sciences 9 (3), 279-284.

Akoachere, J.F., Ndip, R.N. \& Chenwi, E.B., 2002. Antibacterial effect of Zingiber officinal and Garcinia kola on respiratory tract pathogens. East African Medical Journal, 97,588-92. DOI: 10.4314/eamj.v79i11.8804

Al-Shuwaili, M.A., Ibrahim, E.I. \& Al-Bayati, M.T., 2015. Effect of dietary herbal plants supplement in turkey diet on performance and some blood biochemical parameters. Global Journal of Bio-science and Biotechnology, 4 (1), 85-89. http://scienceandnature.org/GJBB Vol4(1)2015/GJBB-V4(1)2015-16.pdf

AOAC, 1985. Official Methods of Analysis. Association of Official Analytical Chemists. 14th edition. Washington DC, USA.

Arkan, B.M., Mohammed, A.M. \& Ali, J., 2012. Effect of ginger (Zingiber officinale) on performance and blood serum parameters of broilers. Int.. J. Poult. Sci. 91 (11),143-146. DOI: 10.3923/ijps.2012.143.146.

Azhir, D., Zakeri, A. \& Rezapour, A.K., 2012. Effect of ginger powder rhizome on humeral immunity of broiler chickens. European Journal of Experimental Biology, 2 (6), 2090-2092. www.pelagiaresearchlibrary.com. URL: http://www.imedpub.com/articles/effect-of-ginger-powder-rhizome-on-homural-immunity-of-broiler-chickens.pdf

Bancroft, J., Steven, A. \& Turner, D.R., 1996. Theory and practice of histological techniques. 4th edition. Churchill Livingstone, Edinburgh. Doi: 10.1002/ (SICl) 1096-9896.

Bhandari, U., Kanojia, R. \& Pillai, K.K., 2005. Effect of ethanolic extract of Zingiber officinale on dyslipidaemia in diabetic rats. J. Ethnopharmacol. 97,227-230. Doi: 10.1016/j.jep.2004.11.011

Botsoglou, N.A., Florou-Paneri, E., Christaki, E., Fletouris, D.J. \& Spais, B.A., 2002. Effect of dietary oregano essential oil on performance of chickens and on iron-induced lipid oxidation of breast, thigh and abdominal fat tissues. Br. Poult. Sci. 43, 223-230. Doi: 10.1080/00071660120121436.

Bowen, R, 2011. Villi, crypts and the life cycle of small intestinal enterocytes. http://www.vivo.colostate.edu/hbooks/pathphys/ digestion/smallgut/lifecycle.html.

Brugh, M.G.A., 1978. Simple method for recording and analyzing serological data. Avian Disease 22, 362-365. DOI,10.2307/1589552.

Demir, E., Sarica, S., Ozcan, M.A. \& Suicmez, M., 2003. The use of natural feed additives as alternative for an antibiotic growth promoter in broiler diets. Br. Poult. Sci. 44, 44-45. Doi: 10.1080/713655288.

Devegowda, G., 1996. Herbal medicines, an untapped treasure in poultry production. Proceedings, 20th World Poultry Congress, September 2-5, 1996, New Delhi, India.

Doumas, B.T., Bayso, D.D., Carter, R.J., Peters, T. \& Schaffer, R., 1981. Determination of total serum protein. Clin. Chem. 27, 1642-1643

Eilers, R.I., 1967. Notification of final adaptation of an international method and standard solution for hemoglobinomerty: Specific for preparation of standard solution. Am. J. Clin. Path. 47, 212-314. https://www.researchgate.net.

El-Deek, A.A., Attia, Y.A., Maysa, M. \& Hannfy, M., 2002. Effect of anise (Pimpinella anisum), ginger (Zingiber officinale Roscoe) and fennel (Foeniculum vulgare) and their mixture on performance of broilers. Archiv fur Geflugelkunde, 67,92-96.

Erener, G., Ocak, N., Ak, F.B. \& Ve-Altop, A., 2005. Performance of broiler fed peppermint (Menthol) or origan (Carvacrol) essential oil supplemented diet. Proceedings of 3rd National Congress of Animal Nutrition, 7-10 September, Adana, Turkey. pp. 58-62.

Ficker, C.F., Smith, M.L. Leaman, D.L., Irawati, C. \& Amason, J.T., 2003. Inhibition of human pathogenic fungi by member of Zingiberaceae used by Kenyah Indonesian borneo. J. Ethnopharmacol. 85 (2-3), 289-293.

Freeman, F. \& Kodera, Y., 1995. Garlic chemistry: Stability of S-(2- propenyl) 2-propene-1-sulfino Panchagavya thioate (allicin) in blood, solvents, and stimulated physiological fluids. J. Agric. Food Chem., 43, 2332-2338. Doi: 10.1021/jf00057a004.

George, O.S., Kaegon, S.G. \& Igbokwe, A.A., 2015. Feed additive effects of graded levels of ginger (Zingiber Officinale) on serum metabolites of broilers. J. Agric. Vet. Sci. 8, 59-62. Doi: 10.9790/2380-08325962.

Giorgio, D.J., Henry, R., Cannon, D. \& Winkelman, J., 1974. Non-protein nitrogenous constituents in clinical chemistry: Principles and Technics. 2nd edition. Harper \& Row New York, 503-557.

Great, H., 2003. Plants and plant extracts for improving animal productivity. Proc. Nutr. Soc. 6, $279-290$. https://doi.org/10.1079/PNS2002197.

Grimes, S.E., 2002. A basic laboratory manual for the small-scale production and testing of I-2 Newcastle disease vaccine. In FAO Regional Office for Asia and the Pacific, Bangkok, Thailand, pp 139. http://www.fao.org/3/aac802e.pdf

Habibi, R., Sadeghi, G.H. \& Karimi, A., 2014. Effect of different concentrations of ginger root powder and its essential oil on growth performance, serum metabolites and antioxidant status in broiler chicks under heat stress. Br. Poult. Sci. 55,228-237.

Hepler, O.E., 1966. Manual of clinical laboratory methods. Charles C Thomas, Sparing Field, Illinois. 
https://www.amazon.com/Manual-Clinical-Laboratory-Methods.

Herawati, 2010. The effect of red ginger as phytobiotic on body weight gain, feed conversion and internal organs conditions of broilers. Int. J. Poult. Sci. 9, 963-967. Doi: 10.3923/ijps.2010.963.967.

Herawati \& Marjuki, 2011. Effect of feeding red ginger as phytobiotic on broiler slaughter weight and meat quality. Int. J. Poult. Sci. 10, 983-986. Doi: 10.3923/ijps.2011.983.986.

Hosseini, M.N., 2011. Comparison of using different level of black pepper with probiotic on performance and serum composition on broilers chickens. Journal of Basic and Applied Scientific Research 1 (11), 2425-2428.

Hui, Y.H., 1996. Oleoresins and essential oils. In: Hui YH, editor. Bailey's industrial oil and fat products. New York: WileyInterscience Publication, cap., 6,145-153. http://onlinelibrary.wiley.com/book/10.1002/047167849X.

Incharoen, T. \& Yamauchi, K., 2009. Production performance, egg quality and intestinal histology in laying hens fed dietary dried fermented ginger. Int. J. Poult. Sci. 8, 1078-1085. Doi: 10.3923/ijps.2009.1078.1085.

Karangiya, V.K., Savsani, H.H., Patil, S.S., Garg, D.D., Murthy, K.S., Ribadiya, N.K. \& Vekariya, S.J., 2016. Effect of dietary supplementation of garlic, ginger and their combination on feed intake, growth performance and economics in commercial broilers. Vet. World 9, 245-250. Doi: 10.14202/vetworld.2016.245-250.

Kawahara, E., Ueda, T. \& Nomura, S., 1991. In vitro phagocytic activity of white spotted shark cells after injection with Aeromoas salmonicida extraceular products. Gyobyo. Kenkyu, Japan, 26,213-214. Doi: 10.3147/jsfp.26.213.

Kind, P.R.N. \& King, E.J., 1954. Estimation of plasma phosphatase by determination of hydrolysed phenol with aminoantipyrine. J. Clin. Path. 7 (4), 322-326. https://www.ncbi.nlm.nih.gov/pubmed/13286357/PMCID:PMC1023845.

Lucas, A.M. \& Jamroz, C., 1961. Atlas of avian hematology. Agriculture Monograph. 25, USDA, Washington, DC. https://www.ncbi.nlm.nih.gov/pmc/articles/PMC1244156

Lucky, Z., 1977. Methods for diagnosis of fish disease. Ameruno, New Delhi, New York.

Malekizadeh, M., Moeini, M.M. \& Ghazi, S., 2012. The effects of different levels of ginger (Zingiber officinale Rosc) and turmeric (Curcuma longa Linn) rhizome powder on some blood metabolites and production performance characteristics of laying hens. J. Agric. Sci. Technol. 14, 127-134. https://www.iasj. net/iasj?func=fulltextandald=49214.

Manesh, M.K., Kazemi, S. \& Asfari M., 2012. Influence of poly germander (Teucrium polium) and watercress (Nasturtium officinale) extract on performance, carcass quality and blood metabolites of male broilers. Research Opinions in Animal and Veterinary Science 2, 66-68. http://roavs.com/pdf-files/Issue_2_2012/66_68.pdf.

Mathivanan, R. \& Kalaiarasi, K., 2007. Panchagavya and Andrographis panculata as alternatives to antibiotic growth promoters on haematological, serum biochemical parameters and immune status of broilers. J. Poult. Sci. 44, 198-204.

Maxine, M.B., 1985. Outline of veterinary clinical pathology. 3rd edition. The lowa State University Press, USA.

Nidaullah, H., Durrani, F.R., Ahmad, S. Jan, I.U. \& Gul, S., 2010. Aqueous extract from different medicinal plants as anticoccidial, growth promotive and immunostimulant in broilers. J. Agric. Biol. Sci. 5 (1), 53-59. http://www.arpnjournals.com/jabs/research_papers/rp_2010/jabs_0110_175.pdf.

NRC, 1994. National Research Council: Nutrient Requirements of Poultry. 9th edition. National Academy Press. Washington, DC., USA.

Oladele, O.A., Emikpe, B.O. \& Bakare, H., 2012. Effects of dietary garlic (Allium sativuml Linn.) supplementation on body weight and gut morphometry of commercial broilers. Int. J. Morphol. 30 (1), 238-240. Doi: 10.4067/S071795022012000100042.

Omar, J.A., Hejazi, A. \& Badran, R., 2016. Performance of broilers supplemented with natural herb extract. Open Journal of Animal Science 6 68-74. Doi: 10.4236/ojas.2016.61009

Onimisi, P.A., Dafwang, I.I. \& Omage, J.J., 2005. Growth performance and water consumption pattern of broiler chicks fed graded levels of ginger waste meal. J. Agric. For. Social Sci. 3 (2): 113-119.

Onu, P.N., 2010. Evaluation of two herbal spices as feed additives for finisher broilers. Biotechnol. Anim. Husb. 26 (5-6), 383-392. Doi: 10.2298/BAH10063830.

Reinhold, R.R. 1953. Determination of serum albumin. Clinical Chemistry 21,1370-1372.

Reitman, S. \& Frankel, S.A. 1957. Colorimetric method for determination of serum glutamic oxaloacetic and glutamic pyruvic transaminase. Am. J. Clin. Path. 28, 56-63. https://www.ncbi.nlm.nih.gov/pubmed/13458125.

Saeid, J.M., Arkan, B.M. \& Al-Baddy, M.A., 2010. Effect of aqueous extract of ginger (ZingiberOfficinale) on blood biochemistry parameters of broiler. Int. J. Poult. Sci. 9 (10), 944-947. Doi: 10.3923/ijps.2010.944.947.

SAS, 2004. Statistical user's guide. INT. Cary, NC. USA.

Schleicher, A., Fritz, Z. \& Kinal, S., 1998. Zastosowanie wybranych ziół w mieszankach treciwych dla kurczt rzenych [The use of some herbs in concentrates for broiler chickens]. Rocz Nauk Zootech 25, 213-244 (in Polish).

Shanoon, A.K., Jassim, M.S., Amin, Q.H. \& Ezaddin, I.N., 2012. Effects of ginger (Zingiber officinale) oil on growth performance and microbial population of broiler Ross. Int. J. Poult. Sci. 11, 589-593. Doi: 10.3923/ijps.2012.589.593.

Sharma, I., Gusain, D. \& Dixit, V.P., 1996. Hypolipidemic and antiatherosclerotic effects of Zingiber officinale in cholesterol fed rabbits. Phytotherapy Res. 10, 517-518. Doi:_10.1002/ (SICI) 1099-1573(199609)10:63.3.CO; 2-C.

Sidney, P.G. \& Barnard, R., 1973. Improved manual spectrophotometric procedure for determination of serum triglycerides. Clin. Chem. 19, 1077-1078. https://www.ncbi.nlm.nih.gov/pubmed/4744812.

Tapsell, L.C., Hemphill, I., Cobiac, L., Patch, C.S., Sullivan, D.R., Fenech, M., Roodenrys, S., Keogh, J.B., Clifton, P.M., Williams, P.G., Fazio, V.A. \& Inge, K.E., 2006. Health benefits of herbs and spices: The past, the present, the future. Med. J. Aust. 185, 4-24. https://www.ncbi.nlm.nih.gov/pubmed/ PMID: 17022438. 
Trinder, P., 1969. Determination of glucose in blood using glucose oxidase with an alternative oxygen acceptor. Ann. Clin. Biochem. 6, 24-27. Doi: 10.1177/000456326900600108.

Zena, K., Mengistu, A. \& Singh, H., 2017. Effect of oyster mushroom, garlic and ginger as feed additives on feed intake, growth performance and economic efficiency of broilers. Br. J. Poult. Sci. 6 (1), 07-15. Doi: 10.5829/idosi.bjps.2017.07.15.

Zhang, G.F., Yang, Z.B., Wang, Y., Yang, W.R., Jiang, S.Z. \& G.S., Gai. 2009. Effects of ginger root (Zingiber officinale) processed to different particle sizes on growth performance, antioxidant status, and serum metabolites of broiler chickens. Poult. Sci. 88, 2159-2166. Doi: 10.3382/ps.2009-00165.

Zhang, X.F. \& Tan, B.K.H., 2003. Effects of an ethanolic extract of Gynura procumbens on serum glucose, cholesterol and triglyceride levels in normal and streptozotocin- induced diabetic rats. Singapore Medical Journal 41, 1-6. 